\title{
Early plasma protein and mineral changes after surgery: a two stage process
}

\author{
MA MYERS, ${ }^{*}$ A FLECK, ${ }^{*}$ B SAMPSON,${ }^{*}$ CM COLLEY,${ }^{*} \mathrm{~J}$ BENT, $\dagger \ddagger$ G HALL $\dagger$ \\ From the *Department of Chemical Pathology, Charing Cross Hospital Medical School, \\ London W6 8RF, and the +Department of Anaesthetics, Hammersmith Hospital, London W12 OHS
}

SUMMARY Sequential changes in albumin, transferrin, $\alpha_{1}$-acid glycoprotein, $\mathrm{C}$ reactive protein, fibrinogen, copper, iron, and zinc in plasma up to $24 \mathrm{~h}$ after hysterectomy were measured. No increases in the concentrations of the acute phase proteins $\alpha_{1}$-acid glycoprotein, $\mathrm{C}$ reactive protein, and fibrinogen were observed until $6 \mathrm{~h}$ after the skin incision. These increases were preceded by significant falls at 2-4 h, and this was shown also by albumin, transferrin, iron, zinc, and copper. The ratios of iron and zinc to their binding proteins, transferrin and albumin, did not decrease until 4-6 $\mathrm{h}$ and their concentrations remained low for at least $24 \mathrm{~h}$. These patterns suggest that at least two mechanisms operate after trauma. The early fall in the concentrations of the proteins in plasma is consistent with a prompt increase in microvascular permeability. The later decrease in binding of the metals iron and zinc to their transport proteins and the increase in concentrations of the acute phase proteins could be initiated by a common mediator.

The acute phase response is a non-specific response to the stimulus of tissue injury or infection.' Several organs and tissues are affected, including the liver, ${ }^{2}$ bone marrow, ${ }^{3}$ muscle ${ }^{4}$ pancreas, ${ }^{5}$ and hypothalamus. ${ }^{\circ}$ Studies on experimental animals have led to the suggestion that one mediator is responsible for the various effects on different organs. ${ }^{78}$ Several names have been applied to this mediator: endogenous pyrogen," leucocytic endogenous mediator, ${ }^{10}$ lymphocyte activating factor, " and interleukin $1 .^{12}$ The last is the current accepted name for the mediator. Because of difficulties in purification, much early experimental work was carried out with crude preparations of interleukin $1 .^{1314}$ Subsequently, it has been suggested that interleukin 1 may be a group of closely related molecules, ${ }^{15}$ and that there may be several mediators responsible for the pattern of the acute phase protein response, each with its own predominant target organ and function. ${ }^{16}$

We have shown previously' that there is a delay of 6-8 $\mathrm{h}$ after tissue injury before there is any increase in concentration of acute phase proteins. This delay is compatible with the hypothesis that a mediator

\section{Accepted for publication 9 May 1984}

‡Present address: Royal Victoria Hospital, 687 Pine Avenue West, Montreal, Quebec, Canada H3A 1A1. such as interleukin 1 is necessary for the acute phase protein response to occur. We now report additional observations of changes in some components of the blood during the first few hours after tissue damage, which give an indication of whether it is likely that more than one mediator is concerned.

\section{Material and methods}

Thirteen patients undergoing hysterectomy were studied. None had a $C$ reactive protein concentration greater than $10 \mathrm{mg} / \mathrm{l}$ before operation and none had signs of infection or systemic disease. The ages of the women ranged from 30 to 55 years (mean $41.7)$. Halothane was used as anaesthetic with or without additional epidural analgesia. All operations were performed before $12.30 \mathrm{pm}$, with a maximum blood loss of $640 \mathrm{ml}$ (mean $320 \mathrm{ml}$ ). Samples of venous blood $(15 \mathrm{ml})$ were taken immediately before the operation and at two hourly intervals thereafter until $12 \mathrm{~h}$ after the operation. Additional blood samples were taken at 24,48 , and $120 \mathrm{~h}$. Plasma (EDTA) and serum were separated by centrifugation as soon as possible and stored at $-20^{\circ} \mathrm{C}$ until assays could be carried out. All samples from one patient were assayed within the same batch for all tests.

End point nephelometry' ${ }^{\prime}$ was used to determine C reactive protein (above $10 \mathrm{mg} / \mathrm{l}), \alpha_{1}$-acid glyco- 
protein, and transferrin concentrations. The within batch coefficients of variation (CV) for nephelometric assays were less than $5 \%$. Concentrations of $\mathrm{C}$ reactive protein below $10 \mathrm{mg} / \mathrm{l}$ were determined by radioimmunoassay using a modification of the methods of Claus et al ${ }^{17}$ (within batch CV $11.8 \%$ ). Albumin was determined by the bromocresol green method'x (within batch $\mathrm{CV}$ $1 \cdot 4 \%$ ). Cortisol was determined by the fluorimetric procedure of Spencer-Peet ${ }^{14}$ (within batch CV 3.3\% at $675 \mu \mathrm{m} / 1$ and $8.4 \%$ at $231 \mu \mathrm{m} / \mathrm{l}$ ).

Fibrinogen was assayed by measuring the fibrin clot using the method of Blomback ${ }^{21}$ (within batch CV $5.9 \%$ ). Iron was measured colorimetrically using the method of Henry=1 (within batch CV less than $3.7 \%$ ), and zinc and copper were measured by automated atomic absorption"2 (within batch $\mathrm{CV}$ of $2.7 \%$ for both assays). Packed cell volume was measured using a microcentrifuge and changes in protein concentration due to fluid shifts were corrected by normalising the packed cell volume to that before operation using the calculation:

$$
\operatorname{Pn}=\operatorname{Ps} \times \frac{1-V_{t}}{1-V_{0}}
$$

where $\mathrm{Pn}=$ normalised protein concentration, $\mathrm{Ps}=$ protein concentration of sample, $V_{0}=$ packed cell volume at time $0, \mathrm{Vt}=$ packed cell volume of sample.

Statistical analysis was carried out by paired $t$ tests.

\section{Results}

In all patients studied the packed cell volume fell after operation, illustrating the necessity to correct

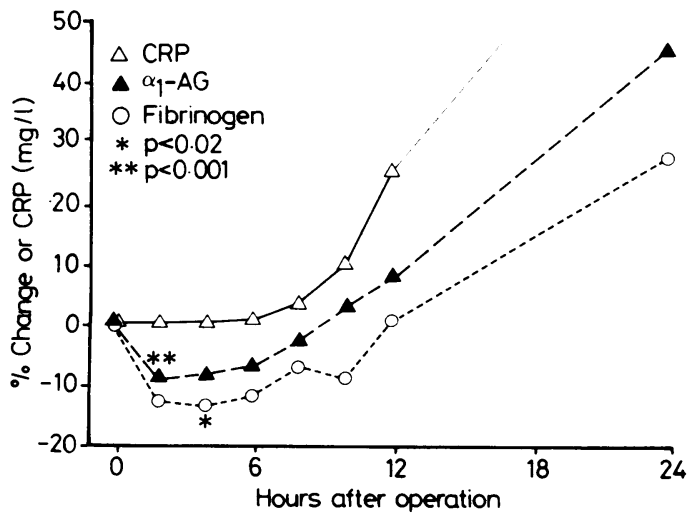

Fig. 1 Changes in protein concentrations after operation. $C$ reactive protein $(C R P)$ was increased to $85 \mathrm{mg} / \mathrm{l}$ at $24 \mathrm{~h}$. $\alpha_{1}-A G=\alpha_{1}$-acid glycoprotein.

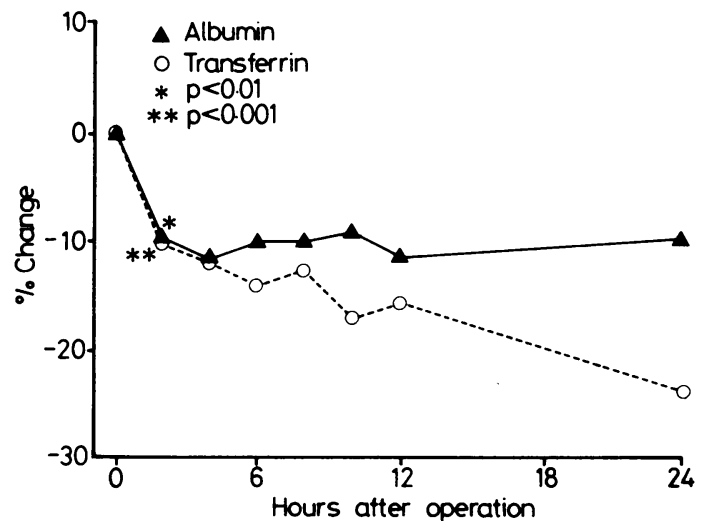

Fig. 2 Changes in protein concentrations after operation.

for haemodilution. With the exception of cortisol, all the variables described here have been corrected for such dilution. A check of the suitability of this correction was made using a computer model (Fleck $A$, Colley CM, Clark B, unpublished data) which indicated that up to $6 \mathrm{~h}$ after operation the average error in corrected values was less than $+1 \%$.

The general pattern of the changes in $\mathrm{C}$ reactive protein, $\alpha_{1}$-acid glycoprotein, fibrinogen, and cortisol are similar to those described previously;' as before, zero time was taken as the initial skin incision. The peak concentration of cortisol occurred at 6-8 $\mathrm{h}$, and there was a delay of 6-8 h before the concentrations of the proteins $\mathrm{C}$ reactive protein, $\alpha_{1}$-acid glycoprotein, and fibrinogen began to increase. Peak $\mathrm{C}$ reactive protein concentration occurred at $48 \mathrm{~h}$ and both $\alpha_{1}$-acid glycoprotein and fibrinogen were still considerably raised at $120 \mathrm{~h}$.

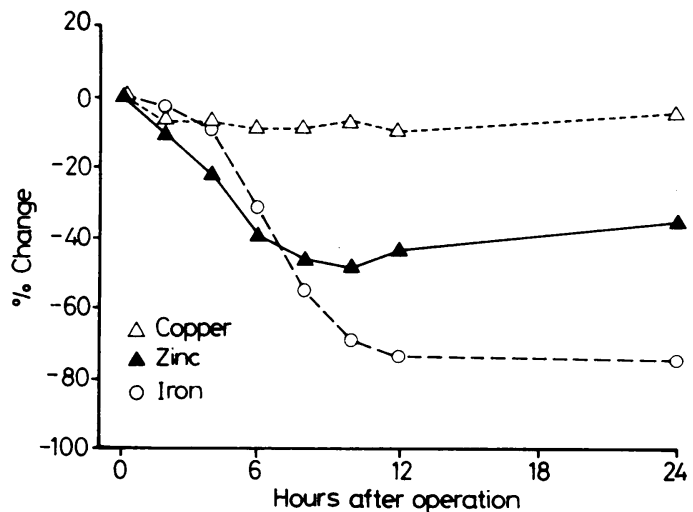

Fig. 3 Changes in metal concentrations after operation. The concentration of zinc was significantly decreased at $2 \mathrm{~h}$ $(p<0 \cdot 05)$, iron at $6 h(p<0 \cdot 001)$, and copper at $2 h$ $(p<0 \cdot() 1)$. 
Two hours after the operation, however, the concentration of $\alpha_{1}$-acid glycoprotein was significantly less than the preoperative value $(p<0.001)$ and the concentration remained lower than the zero time value until $6-8 \mathrm{~h}$, after which the concentration increased (Fig. 1). This fall in concentration before the rise was also noted for fibrinogen (significant at $4 \mathrm{~h}, \mathrm{p}<0.02$ ); the concentration remained low until 6-8 h, after which it increased (Fig. 1). The concentration of $C$ reactive protein fell slightly at $2-4 \mathrm{~h}$, but this was not significant, and after a delay of 6-8 h the concentration increased sharply (Fig. 1).

The concentrations of albumin and transferrin were also reduced at $2 h(p<0.01$ and $p<0.001$ respectively, Fig. 2 ). In contrast with the acute phase proteins the concentrations of albumin and transferrin remained decreased for at least two days, after which there was some increase towards the preoperative values.

The concentrations of both iron and zinc fell rapidly after operation. Zinc reached a minimum at $10 \mathrm{~h}$ (Fig. 3), but the fall was significant at $2 \mathrm{~h}(\mathrm{p}<$ 0.05 ). The concentration of zinc remained low for at least two days and approached the preoperative value after four to five days. Iron reached a minimum 12-24 h after operation (Fig. 3); the decrease was highly significant by $6 \mathrm{~h}(\mathrm{p}<0.001)$. The concentration of iron was still considerably decreased four to five days after operation.

A significant decrease $(p<0.01)$ in the concentration of copper was seen at $2 \mathrm{~h}$ (Fig. 3). This fall was not as pronounced as that seen for iron and zinc, and at four to five days the concentration was significantly increased $(\mathrm{p}<0.001)$ compared with the value at zero time.

\section{Discussion}

The 6-8 $\mathrm{h}$ delay before the increase in concentrations of the acute phase proteins after moderate surgery' was again seen in this study. The pattern of change in plasma cortisol was also the same as that previously reported after herniorrhaphy. ' It is therefore likely that the general pattern of changes in $\mathrm{C}$ reactive protein, fibrinogen, and $\alpha_{1}$-acid glycoprotein is the same after different types of operation. Plasma cortisol was measured because of previous reports that epidural anaesthesia does not provoke the same degree of rise of plasma cortisol as more widely used procedures ${ }^{23}$ and because it has been suggested that cortisol is essential for the synthesis of acute phase proteins by the liver. ${ }^{24}{ }^{25}$ Six to eight hours after the initial skin incision the concentration of $C$ reactive protein rose rapidly, reaching a peak at $48 \mathrm{~h}$ and then falling quickly again towards the value before operation. Fibrinogen and $\alpha_{1}$-acid glycopro-

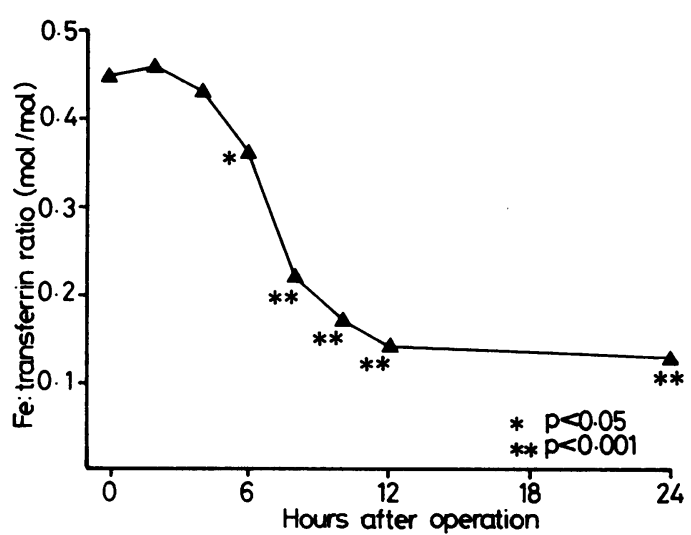

Fig. 4 Iron:transferrin ratio after operation.

tein concentrations both rose after the same lag period as $\mathrm{C}$ reactive protein, with both proteins reaching a plateau at about $120 \mathrm{~h}$. The $6-8 \mathrm{~h}$ delay is compatible with the hypothesis that interleukin 1 is an obligatory intermediate for the acute phase protein response in man.

This does not, however, explain the observation that all proteins measured, with the exception of $C$ reactive protein, showed a significant decrease $2-4 \mathrm{~h}$ after operation. Lamy $e^{t} a^{26}$ have shown a fall in $\alpha_{1}$-antitrypsin after operation, and they suggest that this fall is due to the deposition of the protein at the site of injury. In this study, however, we noted a decrease in concentration of several proteins. Although such a decrease in concentration may be due to consumption of protein-for example, fibrinogen conversion to fibrin-the fact that the proteins measured in this study showed a significant fall raises the possibility of an additional mechanism. As reported elsewhere the transcapillary escape rate

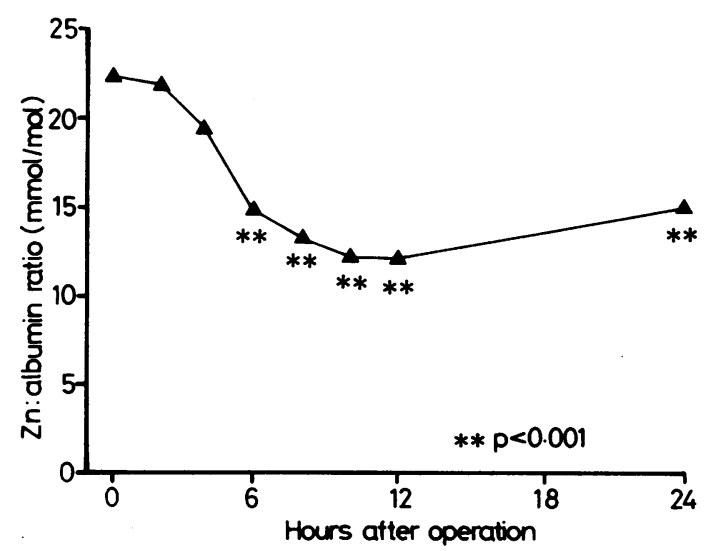

Fig. 5 Zinc: albumin ratio after operation. 
of proteins is increased in chronic illness and rises within hours of cardiac surgery. ${ }^{27}$ We suggest that the early fall in plasma protein concentrations noted here is due to a rapid increase in transcapillary escape rate. The fall in plasma proteins cannot be explained by changes in posture as the patient was recumbent before operation and for at least $12 \mathrm{~h}$ after surgery; nor could it be due to changes in synthesis or catabolism because the changes in concentration were too rapid. Although infusion of fluid will dilute the plasma proteins, the rate of infusion in these patients (average $320 \mathrm{ml} / \mathrm{h}$ ) could not account for more than $1.5 \%$ of the early fall in corrected concentration of the proteins measured (Fleck A, Colley CM, Clark B, unpublished data). We think it unlikely that anaesthesia could be a significant factor in the fall in concentration of some of the plasma proteins reported here. Firstly, we have previously reported that less serious surgery leads to a similar acute phase response but no fall in albumin.' Secondly, decreases in albumin concentrations have been noted after many forms of accidental trauma and elective surgery. ${ }^{28}$ The temporal differences suggest that different mediators may be responsible for the general decrease and for the acute phase response.

Serum iron is mostly bound to transferrin, ${ }^{24}$ and about $65 \%$ of plasma zinc is bound to albumin and $35 \%$ to $\alpha_{2}$-macroglobulin. ${ }^{30}$ The amount of zinc bound to $\alpha_{2}$-macroglobulin is constant, at about 1 mole zinc/mole $\alpha_{2}$-macroglobulin ${ }^{31}$ and this zinc is metabolically unavailable.

As we anticipated from the decrease in transferrin and albumin, early decreases in the concentrations of serum iron (significant at $6 \mathrm{~h}$ ) and zinc (significant at $2 \mathrm{~h}$ ) were seen after operation. The proportion of iron bound remained constant for $4 \mathrm{~h}$, however; at $6 \mathrm{~h}$ the iron bound to transferrin was decreased (Fig. 4). These observations are consistent with a prompt increased loss of transferrin from the vascular system due to a rise in transcapillary escape rate, with a concomitant fall in plasma iron. Subsequently, at about $6 \mathrm{~h}$ after operation iron begins to be removed from the transferrin molecule. Similarly, the zinc to albumin ratio is constant for $4 \mathrm{~h}$ after operation, and at $6 \mathrm{~h}$ the zinc bound to albumin decreases (Fig. 5). The timing of the changes in protein-bound iron and zinc appears to be similar to that of the rise in acute phase proteins, which may indicate a common mediator for both processes. This decrease in iron and zinc is consistent with evidence that iron and zinc are taken up from the blood by the liver after stimulation by interleukin $1 .^{32}$ This has led to the suggestion ${ }^{10}$ that measurement of the early decrease in zinc could be used as a measure of interleukin 1 activity. We suggest, however, that owing to the increase in transcapillary escape rate, the early fall in zinc cannot be used as an indicator and only measurements made after $6 \mathrm{~h}$ may indicate interleukin 1 activity.

Plasma copper is almost completely bound to caeruloplasmin, and we assume that the drop in copper (Fig. 3) was due to a fall in caeruloplasmin caused by an increase in transcapillary escape rate. Caeruloplasmin is an acute phase protein and the rise in copper seen at four to five days was probably due to the rise in the carrier protein.

Thus we conclude firstly that at least two separate mechanisms operate after trauma. Initially, there is a prompt increase in vascular permeability. This is followed by production of interleukin 1 , which has at least two different effects on the liver-synthesis of acute phase proteins and uptake of iron and zinc. Secondly, there is as yet no valid measure of the effects of interleukin 1 on plasma proteins or protein bound elements such as iron or zinc in the period of $0-6 \mathrm{~h}$ after the initial tissue damage.

\section{References}

' Colley CM, Fleck A. Goode AW, Muller BR. Myers MA. Early time course of the acute phase response in man.J Clin Pathol 1983:36:203-7.

${ }^{2}$ Belfrage S. Plasma protein pattern in the course of acute infectious disease. Acta Med Scand 1963;suppl 395:1-169.

${ }^{3}$ Finch SC. In: Williams WJ, Buetter E. Ersler AJ, Rundles RW, eds. Haematology. 2nd ed, New York: McGraw-Hill, 1977:746-75.

‘ Long CL, Birkhaln RH. Gieger JW. Betts JE, Schiller WR, Blakemore WS. Urinary excretion of 3-methylhistidine as assessment of muscle protein catabolism in adult normal subjects during malnutrition sepsis and skeletal trauma. Metabolism 1981;30:765-76.

s Beisel WR. Magnitude of the host nutritional response to infection. Am J Clin Nutr 1977:30:1236-47.

- Bernheim HA, Block LH, Atkins E. Fever: pathogenesis pathophysiology and purpose. Ann Int Med 1979;91:261-70.

${ }^{7}$ Kampschmidt RF. Metabolic alterations elated by endogenous pyrogens. In: Lipton JM, ed. Fever New York: Raven Press, 1980:49-56.

${ }^{*}$ Powanda MC, Beisel WR. Hypothesis: leucocyte endogenous mediator/endogenous pyrogen/lymphocyte activating factor modulates the development of non-specific and specific immunity and affects nutritional status. Am J Clin Nutr 1982:35:762-8.

'Wood Jr WB. Studies on the cause of fever. $N$ Engl $J$ Med 1958;258: 1023.

I" Wannemacher Jr RW, Pekarek RS. Thompson WL, et al. A protein from polymorphonuclear leucocytes (LEM) which affects the rate of hepatic amino acid transport and synthesis of acute phase globulins. Endocrinology 1975;96:651-61.

"Murphy PA, Simon PL, Willoughby WF. Endogenous pyrogens made by rabbit peritoneal exudate cells are identical with lymphocyte-activating factors made by rabbit alveolar macrophages. J Immunol 1980; 124:2498-501.

': Aarden LA, Brunner TK. Cerottini JC, et al. Revised nomenclature for antigen-non specific $T$ cell proliferation and helper factors. J Immunol 1979; 123:2928-9.

${ }^{13}$ Kampschmidt RF. Upchurch HF, Eddington CL. Pulliam LA. 
Multiple biological activities of a partially purified leukocytic endogenous mediator. Am J Physiol 1973;224:530-3.

${ }^{14}$ Merriman CR, Pulliam LA, Kampschmidt RF. Effect of leucocytic endogenous mediator on C-reactive protein in rabbits. Proc Soc Exp Biol Med 1975; 149:782-4.

is Oppenheim JJ, Stadler BM, Siraganian RP, Mage M, Mathieson B. Lymphokines: their role in lymphocyte responses at properties of interleukin 1. Fed Proc 1982;41:257-62.

in Mapes CA, Sobocmski PZ. Differentiation between endogenous pyrogen and leukocytic endogenous mediator. Am J Physiol 1977;232:615-22.

${ }^{17}$ Claus DE, Osmand AP, Gewurz H. Radioimmunoassay of human C-reactive protein and levels in normal sera.J Lab Clin Med 1976;87:120-8.

1* Doumas BT, Watson WD, Briggs HG. Albumin standards and the measurement of serum albumin with bromocresol green. Clin Chim Acta 1971;31:87-96.

${ }^{14}$ Spencer-Peet J, Daly JR, Smith V. A simple method for improving the specificity of the fluorimetric determination of adrenal corticosteroids in human plasma. J Endocrinol 1965;31:23544.

2" Blomback B, Blomback M. Purification of human and bovine fibrinogen. Arkiv Kemi 1956; 10:415-43.

${ }^{21}$ Henry RJ, Sobel C, Chiamori N. On the determination of serum iron and iron binding capacity. Clin Chim Acta 1958;3:523-8.

22 Sampson B. Automated determination of zinc and copper in plasma. Journal of Automatic Chemistry 1983;5:207-9.

${ }^{23}$ Rem J, Brandt MR, Kehlet $\mathrm{H}$. Prevention of post operative lymphopenia and granulocytosis by epidural anaesthesia. Lancet $1980 ; \mathrm{i}: 283-5$.

${ }^{24}$ Thompson WL, Abeles FB, Beall FA, Dintermann RE, Wannemacher Jr RW. Influence of the adrenal glucocorticoids on the stimulation of synthesis of hepatic ribonucleic acid and plasma acute phase globulins by leucocytic endogenous mediators. Biochem J 1976; 156:25-32.

is Jeejeebhoy KN, Ho J, Mehra R, Jeejeebhoy J, Bruce-Robertson A. Effects of hormones on the synthesis of $\alpha_{1}$-(acute phase) glycoprotein in isolated rat hepatocytes. Biochem J 1977: 168:347-52.

${ }^{26}$ Lamy Y, Ibrahim S, Lomanto C, Dombrowiecki A. Sequential changes of $\alpha_{1}$-antitrypsin after surgical trauma. Clin Chim Acta 1978:89:387-91.

${ }^{27}$ Raines G, Fleck A, Ledingham IMcA, Wallace P, Colman KC Increased microvascular permeability to albumin after major surgery, in shock and in cancer patients. Scot Med J 1984; 29:45.

:x Ballantyne FC, Fleck A. The effect of environmental temperature $\left(20^{\circ}\right.$ and $\left.30^{\circ}\right)$ after injury on the concentration of serum proteins in man. Clin Chim Acta 1973;44:341-7.

${ }_{24}$ Bothwell TH, Charlton RW, Cook JD, Finch CA, eds. In: Iron metabolism in man. Oxford, London, Edinburgh, Melbourne: Blackwell Scientific Publications, 1979:284-309.

3" Giroux EL. Determination of zinc distribution between albumin and $\alpha_{2}$-macroglobulin in human serum. Biochem Med 1975; 12:258.

"Song MK. Adham NF. Determination of native zinc content of alpha-2-macroglobulin in normal, hyperzincaemic and hypozincaemic sera by sucrose density gradient centrifugation. Clin Chim Acta 1979;99:13-21.

"2 Pekarek RS, Wannemacher Jr. RW, Beisel WR. The effect of leucocyte endogenous mediator on the tissue distribution of zinc and iron. Proc Soc Exp Biol Med 1972;140:685-8.

Requests for reprints to: Professor A Fleck, Department of Chemical Pathology, Charing Cross Hospital Medical School, Fulham Palace Road, London W6 8RF, England. 